\title{
II. COMMENTARIES
}

„Ante Portas - Security Studies”

2020, No 2(15)

DOI: $10.33674 / 1202011$

\section{Vadim VOLOVOJ ${ }^{1}$ \\ Lithuania}

\section{UKRAINIAN QUESTION - NO GOOD END?}

\section{Abstract:}

There is a deadlock implementing the 'Minsk deal'. The question is what will be the end? The answer will depend on the position of Russia and America. The former doesn't want escalation but is ready for any scenario. The latter is cautious too, but one day, seeking its interests may use the war in Ukraine as a tool in a new geopolitical game. In this case, the disaster of the Ukrainian statehood may happen.

\section{Keywords:}

Minsk deal, Russia, America, Normandy Four, Ukrainian statehood, Donbas, Donetsk, Luhansk, Novorossiya, land corridor to Crimea

\section{Introduction}

Six years have passed since the beginning of the military conflict in Ukraine. It was a hope that the so-called 'Minsk deal' will solve the problem in a way, acceptable to Kyiv, Donbas, Russia, and the West. But now the reality has changed.

Already from the start, it was clear that the 'Minsk deal' was more useful for Russia and Donbas. It was signed by Ukraine after painful military losses and supposed to create a 'state in a state', which would be

1 Vadim Volovoj, PhD, Lithuanian security and global politics expert, CIRSA expert. Email: vadim.volovoj@gmail.com 
very close to Moscow and could block any Western policy of Kyiv. So, there is no surprise that after some time Ukraine with the silent support of the United States and Europe began to sabotage the implementation of the 'Minsk', and many Ukrainian high-level politicians have been fairly declaring that their state signed the deal just to win time and that some conditions are unacceptable to Kyiv ${ }^{2}$.

Thus, today the process moved from the phase when the 'Minsk deal' had to be realized to the phase when Ukraine wants to revise it (first of all, the requirement to change the Constitution and the condition of the control of the border with Russia). Moscow of course is against such an approach, and the deadlock - something like 'No War, No Peace' - has occurred.

Accordingly, there is a question - what is the way out, how the situation will develop? To answer it the main determinants must be formulated. The first one - the position of Russia, the second one - the position of America and (in some part) Europe, the third one - the situation in Ukraine (not the position of the state, which is not relevant, because it fully depends on the West, as separatist Donbas regions do on Moscow).

For now, it seems that today's uncertainty may last a long time (months or even years). If almost nothing has changed for six years, why something must change in another six ones? But historical experience shows that any 'frozen conflict' one day can become 'hot' again. The examples of Georgia (2008) and Karabakh (2020) are more than evident. Then the question is - why the war may start again in Ukraine (who can begin it) and what can be possible consequences for its statehood?

\section{Russia - sleeping bear}

Mike Pense once said that a Russian bear never dies just hibernates. This idea may help to explain Moscow's position on Ukraine. It is clear that the Kremlin is not satisfied with Kyiv's unwillingness to implement the 'Minsk deal', but such a 'middle' situation is better to it than a new war. Several arguments.

\footnotetext{
${ }^{2}$ Kyiv rejects Russia's demands to include Donbas special status in Ukrainian Constitution, <http://uawire.org/kyiv-rejects-russia-s-demands-to-include-donbasspecial-status-in-ukrainian-constitution> (08.11.2020); Minsk agreements impossible to fulfill - Ukraine's Kravchuk, <https://www.unian.info/politics/donbas-war-minskagreements-impossible-to-fulfill-kravchuk-says-11144114.html> (08.11.2020); P. Zayats, Reznikov rasskazal, pochemu Minskiye soglasheniya nevozmozhno vypolnit', <https://ukraina24.segodnya.ua/vlast-news/5349-ministr-rasskazal-pochemuminskie-soglasheniya-nevozmozhno-vypolnit> (08.11.2020).
} 
First, in Georgia Russia before the conflict in 2008 hadn't been demonstrating any signs of aggression. To say more - the situation of uncertainty was useful to it as a tool of influence. Because of Mikhail Saakashvili's actions, it had to react militarily and to recognize the independence of South Ossetia and Abkhazia - the end of the game. At the same time, it decided not to change the regime in Tbilisi despite the possibility to do it.

In 2014 Russia took Crimea only after Maidan win in Kyiv because it decided that it must do it (was its perception of the situation right other question). In 2015 Russia had an opportunity to take more Ukrainian territories, but it didn't take even Mariupol. After that, seeing the politics of Kyiv, it had a lot of pretext to renew the war and, for example, create a land corridor to Crimea and/or take the whole Donetsk oblast and Luhansk oblast, but it didn't do that again.

It is obvious that Russia is not afraid of new American and/or European sanctions, but it is, for example, interested in the realization of the 'Nord Stream 2' project (restarting war in Ukraine could endanger it as the case of Alexey Navalny did, and for Germany, it would be much more difficult to save it in such situation). In other words, Kremlin does not look for additional problems and prefer to wait (for the deeper internal crisis in Ukraine and bigger popularity ${ }^{3}$ of the pro-Russian powers there), also giving Russian citizenship to Donbas people (as in South Ossetia and Abkhazia) and supporting separatists' armies.

But Moscow is ready for any scenario. Russian bear can wake up and go to war if it decides that 'the red line' is crossed (as it was in the case of Crimea in his opinion). Then, the question is - what the Kremlin can percept as 'the red line'? Today president Zelensky strengthens military cooperation with Great Britain and Turkey. There are talks about factual British bases in Ukraine $^{4}$. Such military presence of the West in the very close Russian neighborhood can be unacceptable for Moscow and it can decide to 'cut' Ukraine from the Black Sea. The other thing which can push the Kremlin to military operation - new broad destabilization in Kyiv (new Maidan) and a

\footnotetext{
3 Partiya "Oppozitsionnaya platforma" polozhitel'nootsenila vybory na Ukraine, $<$ https://iz.ru/1078450/2020-10-26/partiia-oppozitcionnaia-platforma-polozhitelnootcenila-vybory-na-ukraine> (26.11.2020).

${ }^{4}$ A. Sharipov, Velikobritaniya Pomozhetukraine sozdat' dve voyenno-morskiye bazy - zamestitel' glavy OP Zhovkva, <https://hromadske.ua/ru/posts/velikobritaniyapomozhet-ukraine-sozdat-dve-voenno-morskie-bazy-zamestitel-predsedatelya-opzhovkva> (09.11.2020).
} 
further escalation in Donbas. Today political and social-economic tension in Ukraine is growing every day, but a lot will depend on the word of America.

\section{America can change the game}

There is 'Normandy Four', but the role of Western Europe in the Ukrainian crisis is not very big. It can try to save this format and to imitate some activity, but, the leading role in the West, solving Ukrainian problems, belongs to Washington. For example, during the last meeting of 'Normandy Four' leaders president Zelensky refused to take back the national military in all points of Donbas, and Russian foreign minister Sergey Lavrov said that this happened because of the position of America $^{5}$. Of course, it is the Russian version, but many signs show that the American word determines the foreign policy of Kyiv.

Even during the presidency of Donald Trump the line of Democrats, who hadn't lost influence in the American foreign policy system, was dominant towards Ukraine (Trump was mainly interested in Joe Biden's personal affairs there as a factor of presidential elections in America). It must be said that despite public aggressiveness towards Russia Biden told Petro Poroshenko not to provoke Russia in Crimea ${ }^{6}$. But this doesn't mean that approach can't change in the future.

Several factors can lead to that. First, desire to get rid of the 'Minsk deal' through new war, because this agreement narrows the maneuver of Ukraine (America). Second, purpose to put more pressure on Russia by the new military conflict to get an advantage in some other sphere. Third, the internal situation in Ukraine can deteriorate in a dangerous way (people will be ready for a new Maidan, and the popularity of the pro-Russian forces will grow rapidly), and only 'external mobilization' through 'Putin's aggression' can help to stabilize it. Finally, Russia can react strongly, if Washington decides to locate its tactical nuclear and/or hypersonic missiles in Ukraine.

\section{Possible consequences}

All these steps are very risky because of one thing - the unpredictable reaction of the Kremlin. America (as in the case of Georgia) may hope that the Ukrainian military (it is very hard to imagine

\footnotetext{
5 Lavrov: Ukraina otkazalas' ot razvedeniya sil povsemu Donbassu iz-za SSHA, <https://www.kommersant.ru/doc/4250348> (09.11.2020).

6 The full version of the Biden and Poroshenko conversation. <https://www.youtube.com/watch?v=fdBzRFJGCtI> (09.11.2020).
} 
that NATO will interfere - at least directly) will be powerful enough to stop Donbas armies, supported by Russia, but it is a miscalculation. Putin clearly said that in case of a Kyiv attack in the East, the Ukrainian statehood will be put in question ${ }^{7}$, and nobody can say, where Russia will stop in this case. There are several scenarios.

In 2019 separatist Donetsk ${ }^{8}$ and Luhansk ${ }^{9}$ Republics adopted the laws, which state that their borders coincide with the borders of Donetsk oblast and Luhansk oblast appropriately. It means that if the war begins, unrecognized Republics can reach these borders. At the same time, Russia can create a land corridor to Crimea and in general 'cut' Ukraine from the Black Sea. To say more, the idea of 'Novorossiya' may be put on the table once again. Finally, Kremlin can decide to change the regime in Kyiv, using Donbas separatists and loyal political forces in Ukraine.

Figure 1. Novorrussian Federation.

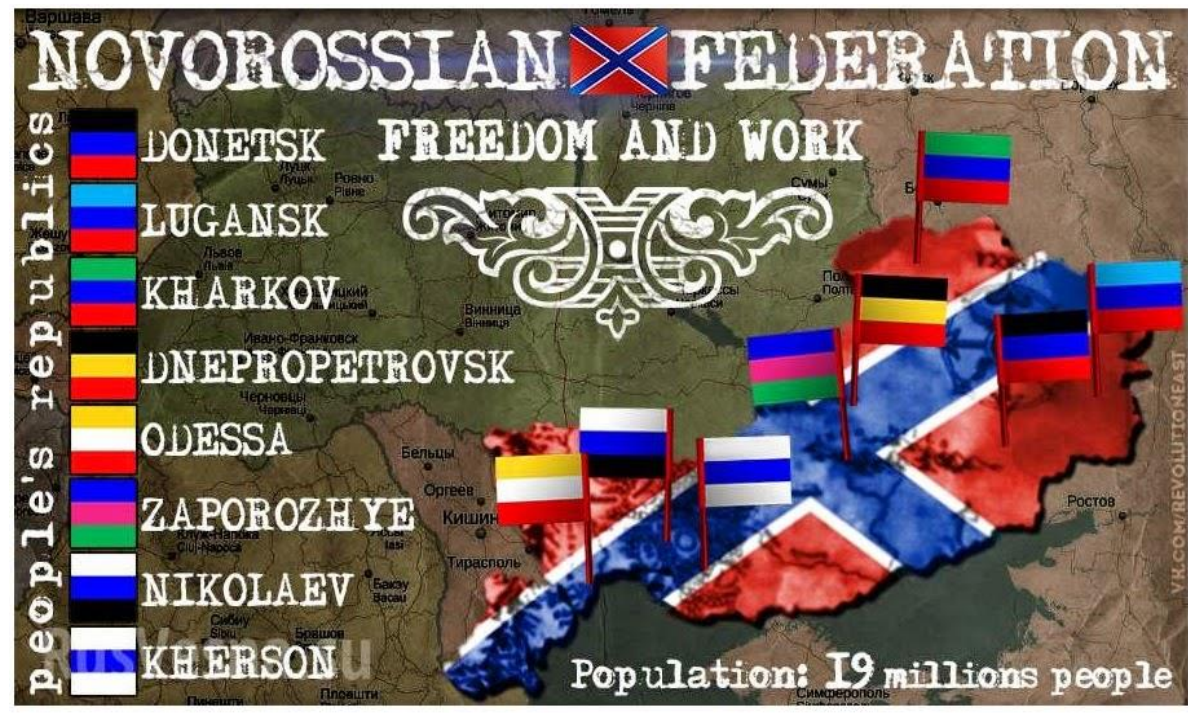

Source: Novorussian Federation?, <http://flag-review.blogspot.com/2015/01/ novorussian-federation.html> (17.11.2020).

\footnotetext{
7 Putin prigrozil Ukraine problemami dlyagosudarstvennosti za ataku na DNR, <https://www.rbc.ru/politics/07/06/2018/5b190ca19a794743fd6aef44> (09.11.2020).

${ }^{8}$ V DNR priyanyali zakon o gosgranitse, <https://ria.ru/20191129/1561741247.html>, (09.11.2020).

${ }^{9}$ VLNR prinyali zakon o granitsesamoprovozglashennoy respubliki, <https://www.rbc.ru/politics/18/12/2019/5dfa27b89a79471864319ec7> (09.11.2020).
} 
Russia's decision where to stop will depend on several moments. First, military success, and is supposed to be fast, keeping in mind the possibilities of the Russian military machine and still poor condition of the Ukrainian army. Second - and much more important - the position of the Ukrainian population in different regions. For example, people in Odesa may be glad to become a part of 'Novorossiya', but people in Dnipro not so much. In other words, Russia (separatists) may take Donetsk oblast, Luhansk oblast, and some other Eastern regions, but not all, because of potential problems with their loyalty (control).

So, minimal scenario - Donetsk oblast, Luhansk oblast, and land corridor to Crimea. It could be an acceptable cost for the West in the context of a broader geopolitical game with Russia, but a territorial disaster for Ukraine. For the moment this is only a hypothetical situation. However, the examples of Georgia and Karabakh show that in the case of the 'frozen conflicts' there is no question 'if the war restarts', but 'when it restarts'.

There is one specific politician in Russia - Vladimir Zhirinovsky. He says a lot of crazy things. Some experts think that he is just a show maker, a political clown. Others propose to listen to him with attention because sometimes he says what Kremlin wants, but cannot say itself openly. So, not so long ago he predicted ${ }^{10}$ that the war in Ukraine may restart in 2021 or 2022 , because Kyiv, pushed by the West, will attack Donbas and Crimea. As a result, 70-80 percent of the Ukrainian territory will become part of Russia, the other one - will join the EU and NATO (Poland and Germany may be involved in the conflict). It looks unreal, but in today's world, unreal things happen too often. Anyway, it seems that there can be no good end to the Ukrainian story.

\section{Conclusion}

The Ukrainian case is very complicated. There was a hope that the 'Minsk deal' will solve the problem, but now the deadlock occurred in the implementation of the agreement. It may last a long time, but the history of the 'frozen conflicts' shows that one day or another they become 'hot' again. The development of the situation will depend mainly on the position of Russia and America. The Kremlin doesn't want to

\footnotetext{
${ }^{10}$ Voyna i razdel Ukrainy proizoydut v 2021-2022godu, - Zhirinovskiy, <https://rusvesna.su /news/1606374914> (26.11.2020).
} 
restart the war but is ready for any scenario. Washington for now is cautious too, but one day may decide to use military conflict in Ukraine to improve American geopolitical position. The possible result - a disaster of the Ukrainian statehood, but it seems that there can be no good end to this story.

\section{Bibliography:}

$\checkmark$ Lavrov: Ukraina otkazalas' ot razvedeniya sil povsemu Donbassu iz-za SSHA, <https://www.kommersant.ru/doc/4250348>

$\checkmark$ Kyiv rejects Russia's demands to include Donbas special status in Ukrainian Constitution, <http://uawire.org/kyiv-rejects-russias-demands-to-include-donbas-special-status-in-ukrainianconstitution>

$\checkmark$ Minsk agreements impossible to fulfill - Ukraine's Kravchuk, $<$ https://www.unian.info/politics/donbas-war-minsk-agreementsimpossible-to-fulfill-kravchuk-says-11144114.html>

$\checkmark$ Novorussian Federation?, <http://flag-review.blogspot.com/2015/ 01/novorussian-federation.html $>$

$\checkmark$ Partiya "Oppozitsionnaya platforma" polozhitel'nootsenila vybory na Ukraine, <https://iz.ru/1078450/2020-10-26/partiia-oppozitcionnaia-platforma-polozhitelno-otcenila-vybory-na-ukraine>

$\checkmark$ Putin prigrozil Ukraine problemami dlyagosudarstvennosti za ataku na DNR, <https://www.rbc.ru/politics/07/06/2018/ 5b190ca19a794743fd6aef44>

$\checkmark$ Sharipov A., Velikobritaniya Pomozhetukraine sozdat' dve voyenno-morskiye bazy - zamestitel' glavy OP Zhovkva, $<$ https://hromadske.ua/ru/posts/velikobritaniya-pomozhet-ukraine-sozdat-dve-voenno-morskie-bazy-zamestitel-predsedatelyaop-zhovkva>

$\checkmark$ The full version of the Biden and Poroshenko conversation. Poroshenko was preparing attack in Crimea, $<$ https://www.youtube.com/watch?v=fdBzRFJGCtI>

$\checkmark V$ DNR priyanyali zakon o gosgranitse, <https://ria.ru/ 20191129/1561741247.html>

$\checkmark \quad V$ LNR prinyali zakon o granitsesamoprovozglashennoy respubliki, <https://www.rbc.ru/politics/18/12/2019/5dfa27b89a 79471864319ec7>

$\checkmark$ Voyna $i$ razdel Ukrainy proizoydut v 2021-2022godu, - 
Zhirinovskiy, <https://rusvesna.su/news/1606374914>

$\checkmark$ Zayats P., Reznikov rasskazal, pochemu Minskiye soglasheniya nevozmozhno vypolnit', <https://ukraina24.segodnya.ua/vlastnews/5349-ministr-rasskazal-pochemu-minskie-soglasheniyanevozmozhno-vypolnit> 